\title{
Tragedy and Satyr Play
}

\section{Mohammad ALMOHANNA \\ The Higher Institute of Dramatic Arts}

The fifth and the fourth century B.C. are important stages in the history of ancient Athens. It was a significant period for Athens, especially since it came after a long stage of political struggle which ended with a great achievement - the formation of a new political system, based on the rule of the people, and termed democracy.

The influence of democracy was reflected in many aspects of the Athenians' life and thus it is possible that this influence reached the realm of ancient drama during the fifth century in Athens.

This paper today will deal with the interrelation between democracy and the dramatic genre called Satyr play; the dramatic genre that flourished and developed in the course of the fifth century Athens.

Storey and Allan ${ }^{1}$ define Satyr- play as: a short drama with a chorus of satyrs (half-human, half-animal followers of Dionysus); it followed the three tragedies and made fun of the serious themes and characters of myth.

The main purpose of this paper is to explore the way that Satyric drama of the fifth century validates one of the most important principles in democracy and that is diversity especially in the fifth and fourth centuries. I will argue in this paper that in the course of the City Dionysia; the major dramatic festival in Athens, there existed a sense of diversity in terms of having two distinctive types of drama sharing the same space but each expressing itself in a distinct way. Thus, I will focus on the interrelationship between tragedy and Satyr play by giving a brief account of formal similarities. Then I will move to look in some detail at the dramaturgy of Satyr play. In the last part of this paper I will be dealing with the reception of Satyr play in the contemporary world, from one specific perspective: 


\section{Tragedy and Satyr Play}

how contemporary playwrights interpret Satyr play to enhance themes related to democracy. My examples are two remarkable adaptations of Sophocles' Satyr play entitled Ichneutai by Tony Harrison from England and Ahmed Etman from Egypt.

We know that the major dramatic festival, the City Dionysia, was organized annually. Each poet participated in the dramatic competition by presenting a tetralogy consisting of three tragedies and one Satyr play. Being fourth after a set of three tragedies, it is possible to see that Satyr play follows the pattern of tragedy in many respects. Let's now highlight some aspects of similarity:

1- Both tragedy and Satyr play are written by tragedian poets.

2- The formal structures of both tragedy and Satyr play are similar. The structure of Euripides' Cyclops is similar to those of tragedy: Prologue - Parodos - Four episodes each followed by stasimon exodus.

3- They share the same stage, performed for the same audience.

4- Both are part of the contest.

5- In terms of content both tragedy and Satyr play borrow their subject from myth and earlier poetry. The subject of Euripides' Cyclops, for example, is taken mainly from the Homeric epic. The ninth book of the Odyssey tells us about Odysseus arriving at the island of the Cyclops. The subject of Sophocles' Ichneutai is about the searching of the lost cattle of Apollo. This story appears in the Homeric Hymn to Hermes. Euripides' Proteus adapts the adventure of Menelaus in the fourth book of the Odyssey.

6- The number of actors in both is likely to be similar. In the Aeschylean Satyr play (e.g. Net-Haulers; Theoroi) three speaking actors, including Silenus, appear on stage at the same time. If Silenus is introduced as the coryphaeus then it is probable that only two actors are required for early Satyr play $^{2}$. If this old tradition were still preserved in later Satyr play after the introduction of the third actor, Cyclops should need only two actors for Odysseus and 


\section{Mohammad ALMOHANNA}

Polyphemus, and Silenus then must be a member of the chorus. This is hardly acceptable since Silenus in this play comes on stage even before the chorus and exits (Cyclops 174), the stage while the chorus remains on stage and later Polyphemus drags him off about 140 lines before the exodus (Cyclops 648). That seems to suggest that the numbers of the actors and members of the chorus in satyr plays still follow the development of the tragic genre from the time of Aeschylus until the time of Euripides. It is perhaps an indication that even if Satyr play was an independent genre in the fifth century B.C. it generally follows tragedy in many aspects.

7- The masks and costumes used for the actors are similar in both tragedy and satyr play. Taplin in his interpretation of the 'Pronomos Vase' notes that 'the mask and costumes of the three main actors show no signs of being different from those of tragedy' 3 .

This is to say that satyr- play of the fifth century shares the space of tragedy and many of its characteristics, but, at the same time, it differs considerably from tragedy played in the same theatrical space. Three important aspects must be discussed:

The treatment of myth in Satyr play is one of these aspects. The writers of Satyr play frequently use the myth as framework for their new adaptations. The outlines of the mythical story are preserved in most if not all of the surviving satyric texts and the essential figures of the myth, whether mortal or immortal, are still represented in these dramatic adaptations, but one noticeable difference between myth and satyr play appears in the way that Satyr playwrights interpret the myth. For example the subject of Sophocles' Ichneutai is borrowed from the Homeric Hymn to Hermes but the ancient playwright makes several changes to the original source to produce a storytelling that suits the genre of Satyr play.

The play starts with the arrival of Apollo at Mount Kyllene searching for his lost cattle, and then he declares a prize for whoever can bring the cattle back to their master. Silenus and the satyrs are the first to respond and decide to take up the mission for the sake of winning the prize which is 


\section{Tragedy and Satyr Play}

now gold and freedom. Such interference of the satyrs in the mythical narration is one of the fundamental aspects of Satyr play, and from this interference the plot of satyr play develops and often provides its special version of the myth.

Soon after they start to track the cattle they find the first clue; the hoofmarks near a cave's entrance but they cannot figure out whether the cattle that entered the cave had all come out as the prints point in both directions. While they are uncertain about this clue a strange soft voice comes out of the cave and terrifies them. They jump on the ground making a noise which finally provokes the mountain nymph Kyllene to come out of the cave and ask the satyrs not to disturb Hermes the infant son of Zeus who is now six days old. The satyrs insist on knowing the source of the strange sound coming from inside the cave; the nymph answers them that this is the sound of the newly invented lyre which Hermes made from the shell of a tortoise. After a series of questions the satyrs figure out that Hermes made the string of his musical instrument out of guts taken from Apollo's cattle. That makes them confident that Hermes is the thief and Kyllene must now let the cattle out of the cave. But she warns them not to abuse the son of Zeus. At this point the papyrus breaks off.

The classical sources, more precisely the Homeric Hymn to Hermes, tell us that this story ends by the exchange of the lyre with the cattle of Apollo who accepts this arrangement. But the details of how Sophocles treated the rest of this story are beyond our reach up to this day. What we can observe from this example is the great influence of the satyric chorus in shaping the subject of Satyr play and the integral role that they gain in this type of dramatic genre.

Epic is also another important source for Satyr play. Euripidus' Cyclops, the only complete surviving example of Satyr play takes its subject from the ninth book of The Odyssey. The play tells the story of Odysseus and his companions arriving at the island of Sicley, near the cave of the one-eyed Cyclops, called Polyphemus. On their arrival they meet with Silenus and his sons, the satyrs, who are now slaves of Polyphemus. As Odysseus and 


\section{Mohammad ALMOHANNA}

his companions were running out of food, he offers Silenus to trade food, originally belonging to his master, for wine. Silenus, as a wine addict and follower of Dionysus, could not refuse such an offer and approved the deal. Once the Cyclops unexpectedly arrived he found Odysseus and his friends eating his food. He punished them by eating some of Odysseus' companions. In return Odysseus decided to flee from the land of Polyphemus but not before taking revenge. He offers wine to Polyphemus who has never tested it before. Once the Cyclops became drunk Odysseus blinds Polyphemus with a burning stake, then flees with his companions, Silenus and the satyrs.

Sommerstein ${ }^{4}$ in his book 'Greek Drama and Dramatists' provides a standard recipe for the typical fifth century Satyr- play, I have summarised this recipe into the following steps with some illustrations:

a- Take a suitable episode from myth that has a happy ending.

b- Make sure that it contains some of the following ingredients: sex, babies, resurrection, athletics, new inventions or discoveries, and a chance for the satyrs to practice a new or unaccustomed occupation $^{5}$.

c- Stir in a chorus of satyrs together with their father 'Silenus'.

d- Stew the whole mixture together.

e- Allow the satyrs to impart a farcical, selfish, amoral flavour to the dish.

f- Finally serve as a dessert to the tragic banquet.

This useful recipe underlines the basic ingredients and the playwright task. There are however two steps in this recipe that I wish to focus on, first the selection of mythical episode for Satyr play, and secondly inserting the satyric chorus into the mythical context.

It is remarkable that Satyr play sometimes integrates a minor event of the myth and reproduces it as the main subject of the play. It also distinguishes itself from tragedy by adapting the mythical narrative into a simple dramatic plot in burlesque mode while the setting in most cases is in 


\section{Tragedy and Satyr Play}

exotic places. In Cyclops the setting is near the seashore before the cave of Polyphemus, in Ichneutai it is before the cave of Maia on the slopes of Mount Kyllene, the seashore of the island of Seriphos in Net-Haulers. Thus it is no longer the royal palace of Agamemnon or Oedipus appropriate to the traditional setting of tragedy.

Such exotic places are the most suitable environment to insert the main ingredient of Satyr play; the satyric chorus. This type of chorus, I think, is another factor enhancing diversity not only in the City Dionysia but within the genre of Satyr drama itself.

Let us consider the major semiotic codes of the Satyric chorus. We know from Satyric iconography that theatrical satyrs normally wear a uniform costume consisting of:

a- A balding, snub nosed, and grotesque mask.

b- Briefs with horse-tail and erect phallus both attached to them.

This costume is unique in ancient dramatic genres and it seems to be the basic costume which is expected to be worn by the satyric-chorus on the stage. This is justified by the fact that much evidence of satyric performance depicts them almost in the same trend in regard to the costume.

The main characteristics of this theatrical costume can be illustrated as the following:

1- It asserts the hybrid animal-human body of the performers.

2- The grotesque mask stresses the paradox between the satyr as a young male while the bald head appropriate for an old male.

Beyond this visual diversity in age group and specie of the satyr we have also a great degree of diversity in the social status of the satyrs. Their status comprises both elevated and degraded rank.

From the beginning satyrs are imaginary mythical creatures who are known in antiquity as the loyal companions of Dionysus. Nevertheless they were at the same time regarded as degraded. Hesiod describes them frankly as 'the race of lazy good-for-nothing satyrs'. They are frequently compared with a wild-man model. This is however not a false charge, one should 


\section{Mohammad ALMOHANNA}

always keep in mind that they are in one way or another beasts of halfhuman and half-animal body.

This dual recognition of the satyr-type provides one of the most fundamental features of the diversity, the conjunction of the sacred and the profane, the old and the young and so on.

The treatment of the heroic characters in Satyr play is very similar to those of tragedy; Odysseus in Cyclops appears to retain his Homeric dignity and is never reduced to the farcical level of the satyrs and Silenus.

The key figures are, then, the satyrs; their integration into the dramatic action enables them to give a new perspective on the myth that often has never been found before in earlier sources

Satyrs tend to displace or perhaps share with the mythical figures their central position in myth, and become a participating party in the main ongoing event of the Satyr play, as a result of this textual tension the central action of the satyr play can be described as an encounter between satyrs and the mythical heroic figure.

Lissarrague persuasively argues that the key element which dominates the relation between Satyr play and myth narrative is the presence of the satyrs. He points out that this relation 'works by playing with myth, by taking a well-known story and overlaying it with a group of satyrs who react to the situation in their own peculiar fashion.

What this type of treatment provides is actually an alternative discourse for serious narration.

My example here is Aeschylus' Lycurgus. This satyr play was the fourth play to: Edonians, Bassarae, and Neaniskoi ( or The Youths).

In the Edonians: the first play of its tetralogy, Aeschylus treated the story of Lycurgus when he persecuted Dionysus and how he captured the bacchants: the female followers of Dionysus ${ }^{6}$. While in the fourth play of this tetralogy, Aeschylus seems to use the same extract of the myth but with a remarkable replacement of satyrs instead of the bacchants ${ }^{7}$. Retelling the story from a new and quite different perspective must have reflected a significant contrast between two genres, especially when both treated the 


\section{Tragedy and Satyr Play}

same extract of the myth. This is also a crucial aspect from the reception point of view because the audience of such productions would see two clashing versions of the same place with quite different modes of imitation sharing the same space.

The diversity of Satyr play seems to be also a key point in reading contemporary reception of Satyr play.I will look briefly at two contemporary adaptation of Sophocles' Ichneutai, one by the English poet Tony Harrison, the other by the Egyptian playwright Prof. Ahmed Etman.

Harrison in his version reconstructs the play of Sophocles using his background in classics. He uses a combination of ancient and contemporary settings to create a series of anachronisms. But the most relevant theme to our discussion today is the theme of marginalization.

Let us first outline the story of Harrison's version. The opening scene is the excavation site of the British expedition at Oxyrhynchus around the end of the $19^{\text {th }}$ century, led by two contemporary Oxford academics: Bernard Pyne Grenfell and Arthur Surridge Hunt. The expedition has recovered many papyri which are now packed in crates ready to be shipped to Oxford. Grenfell is motivated by the ghost of Apollo to find the papyri of Ichneutai. $\mathrm{He}$ is possessed by Apollo himself. At this point the setting shifts to Sophocles' play.

Harrison then adapted the story of Ichneutai. He added the predictable end of the story, as it is told in ancient sources, in which Apollo exchanges his stolen cattle with the lyre of Hermes. As Apollo feels satisfied with this arrangement he carries out his promise to the satyrs and gives them their rewards, each satyr will receive what seems to be, at the first glance, a gold bar. The satyrs, according to the stage direction in the printed text, 'line up for the rewards' of gold which Apollo had pulled out of a crate. They are like children lining up for Santa Claus only they have no excitement at what they receive. Each of the 'gold bars' is in fact a 'ghetto-blaster' wrapped in gold foil.

The false gold prize is not the only source of disappointment for the satyrs; there is yet more bad news. Following the presentation of the prizes 


\title{
Mohammad ALMOHANNA
}

Apollo orders them not to declare their role in finding the stolen cattle and the subsequent events which led to his possession of the lyre. In addition he forbids them from using his instrument as it is now his exclusive instrument to create art.

\author{
Apollo: I'm Apollo, inspirer, appreciator \\ of artists, musician and creator. \\ Tell the truth it didn't suit a god \\ the cowpoke's lariat and cattle prod. \\ I'm not a cowherd really. It's more me \\ the sphere of music and of poetry. \\ This is now my lyre and I define \\ its music as half-human, half-divine \\ And satyrs, I repeat, must not aspire \\ in any way to mastering my lyre. ${ }^{8}$
}

In reaction to their exclusion the satyrs recall their role in civilization, their existence and participation in the first experiences of humankind, and their representation in the dramatic festivals during the classical era.

Silenus: Satyrs in theatre are on hand to reassess
doom and destiny and dire distress.
Six hours of tragedy and half an hour of fun.
But they were an entity conceived as one.
But when the teachers and critics made their selections
they elbowed the satyrs with embarrassing erections.
Those teachers of tragedy sought to exclude
the rampant half-animals as offensive and rude. ${ }^{9}$

They decide to protest by destroying the papyri, the source of knowledge which they have brought to life.

The ancient setting then vanishes. The chorus is transformed into football hooligans who destroy the papyri by forming a football out of them for a six-a-side football match.

The version of Harrison, as in Sophocles' play, keeps the theme of search or tracking as central to the play. But Harrison uses this theme on several levels. What enables him to play around them is the fact that his version, as we mentioned before, contains both mythical and historical characters, western and eastern characters, ancient and contemporary characters. From the theme of searching for the cattle of Apollo he creates the theme of 


\section{Tragedy and Satyr Play}

searching for the papyrus. He finally ended his play with an absurd theme, an open mission for the contemporary satyrs to track down their role, recognition, and rights. By the end of Harrison's play these appeals seem to be unfulfilled, just like the old classical dramatic satyrs they often find themselves empty-handed by the end of a typical Satyr play. Their dreams often vanish when they are reunited with Dionysus rejoining his service.

Harrison adds many ideological themes which collectively form a question about who has an exclusive right to knowledge. This conflict between access to high and low culture is the central debate in Harrison's version.

Etman on the other hand, treats the same conflict between high and low but takes it to another level. It is no longer a class society conflict but a conflict between knowledge and a simple farmer society. The title of his play is The Goats of Oxyrhynchus (معيز البهنسا). It is worth mentioning that the dramatic structure of Etman's version of Ichneutai does not follow the classical pattern, but uses the style of epic theatre. thus the play is divided into six tableaux. The first tableau takes place in Cairo University which hosts an official meeting to review the curriculum and to discuss the proposal of Taha Hussein, the head of the university, to introduce the study of ancient Greek and Latin in the Egyptian universities. The participants in this meeting are all historical figures: a cleric from the holy Azhar, the oldest Islamic university in Cairo, and two European orientalists: Carlo Alfonso Nallino (1872-1938) from Italy and Ludwig Richard Enno Littmann (1875-1958) from Germany. Many objections are raised against the proposal of Hussein but he successfully defends his proposal and convinces the majority to defer the decision for more study.

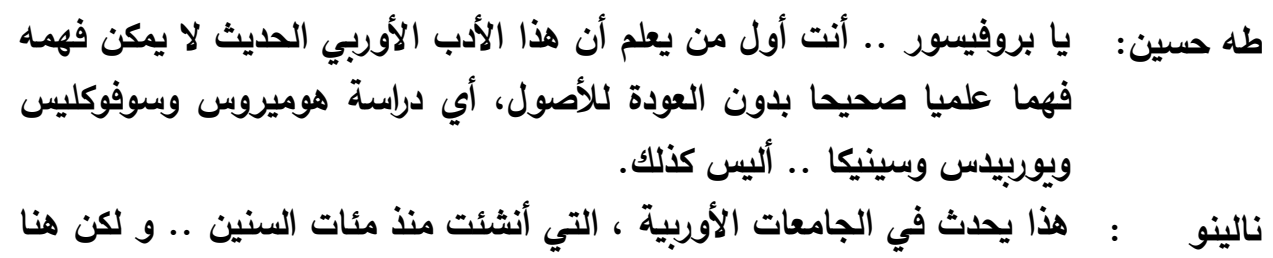




\section{Mohammad ALMOHANNA}

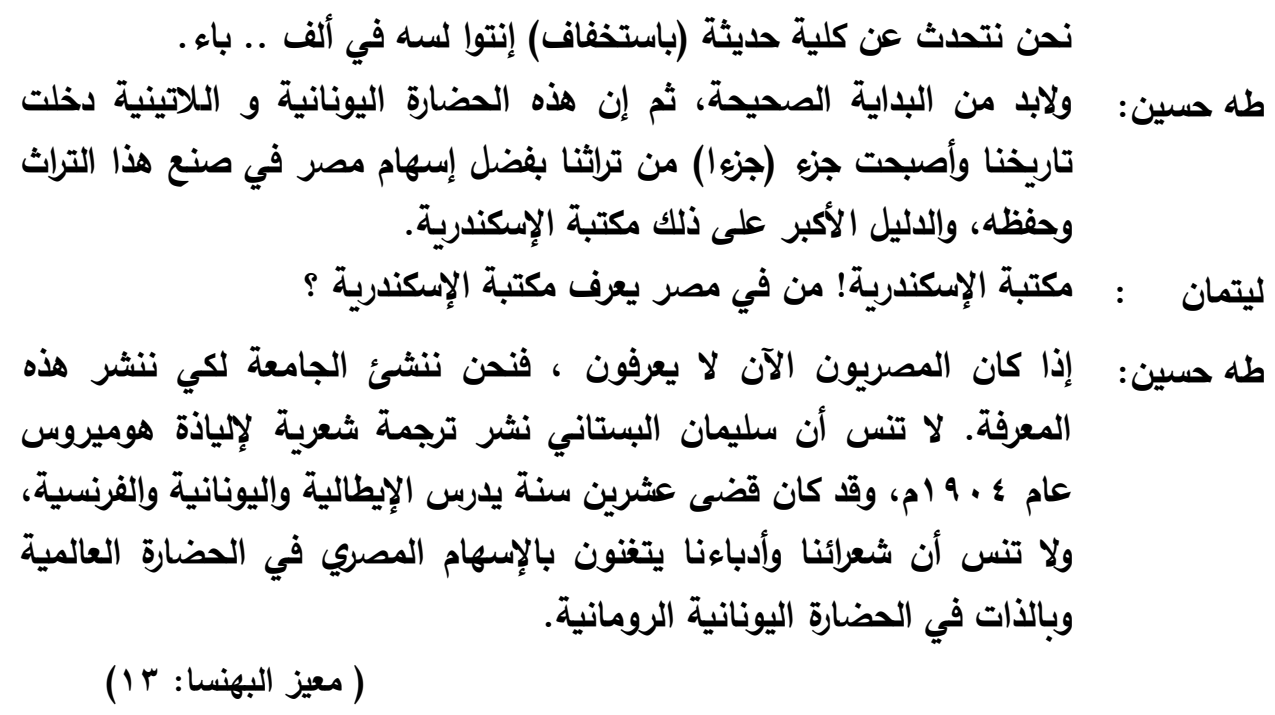

Taha Hussein : (to Nallito) Professor you are the first to know that western literature cannot be understood without a full knowledge of its original roots and without the study of Homer, Sophocles, Euripides, and Seneca. Am I right?

Nallino : $\quad$ this is true but only for universities that have been founded centuries ago, while we are talking now about a budding college, (sniffing) you are merely learning the alphabet!

Taha Hussein: we must make the right start, Greek and Roman culture have entered our history and become part of our heritage, all as a result of Egypt's contribution in preserving this history and revealing it. one cannot deny the example of the library of Alexandria.

Littmann : the library of Alexandria! Who on earth knows anything about it here in Egypt?!

Taha Hussein: if the Egyptians today don't know, we will establish this university to teach them and they are not so far from such knowledge, in 1904 Sulaiman Al-bustani published an Arabic verse translation of the Iliad of Homer for which he spent twenty years learning Italian, Greek, and French. And remember that our poets have praised Egypt's contribution to many cultures in the past particularly to Greek and Roman culture.

(The Goats of Oxyrhynchus: 13) $)^{10}$ 


\section{Tragedy and Satyr Play}

By the end of this tableau Nallino explains that henceforth excavations will be supervised by the Egyptian Council for Antiquity. He also states that the central area for the digging will be Oxyrhynchus. The audience first show their surprise at this unfamiliar name, but soon after they recognize the city by its Egyptian name: Albahnasa.

The second tableau has a totally different setting. It is located at a traditional coffee shop in Albahnasa in front of the excavation site. The scene starts with a conversation between the coffee shop owner and one of his waiters who has been asked to make the appropriate arrangements to host the foreign expedition in the city.

At the beginning of the third tableau we can recognise these characters as two different groups: the local people and the foreign expedition: Grenfell, Hunt and the secretary. Each of these groups is dominated by its own motivations; while the foreigners appear busy examining the papyri, the locals put their efforts into ensuring appropriate hospitality for the guests of their city. Later the Maghannawati (the name of the traditional singer in the Egyptian countryside) starts to sing some folk songs.

In the fourth tableau Hunt and Grenfell start a discussion about the historical role of Oxyrhynchus in preserving the history of the ancient world. Grenfell then declares his ambition to find the papyrus of Sophocles' satyric play, Ichneutai.

The fifth tableau starts with the arrival of the Sheriff's shepherd who expresses his deep regret for the theft of his master's cattle. The Maganwati arrives shortly afterwards to invite the attendants to join him in a folk ceremony called 'Zar and Mendel' to pray for the return of the lost cattle. After the singer starts the ceremony with a local woman a goat is brought for a sacrifice. Afterwards, its skin is worn by the participants in the ceremony. The shepherd calls for the attendants to act as the goat of the god. While the ceremony continues two of the participants step forward and address each other, they are the fathers of the Christian girl Maria and the Muslim Boy Mohammed who love each other but could not be married because of their different religions Since this ceremony unifies them, the 


\section{Mohammad ALMOHANNA}

father of Maria agrees to give his daughter to Mohammed if he succeeds in returning the lost cattle.

The sixth tableau is set in the coffee shop and starts by the singer narrating the adventure of the boy Mohammed searching for the lost cattle and how he travelled far away, fought beasts and killed them until he brought back the lost cattle to the city. Then the arrival of Mohammed and the ceremony of his victory are simulated in the background on the stage.

After this scene Grenfell announces to a press conference the discovery of the Ichneutai papyrus which will improve our knowledge about the satyr-play genre. For Grenfell this discovery is based both on the papyrus and on the folklore and customs of the local people of Albahnasa.

In Etman's play the local society becomes more central and the theatrical space is not the excavation site in the rural area of the city, but is located next to the qahwah; the traditional coffeehouse which gathers people from all around the city, regardless of their background or social class. Harrison thematized the lack of knowledge in fellaheen society; their lack of knowledge led them to damage many papyri when they used them as manure or fertilizer for farming purposes. Etman preserves the same attitude by giving another example of abuse of papyri. He shows that the local people used the papyri for cooking purposes. However both Harrison and Etman thus show the paradox that these ordinary people, who have no clue about the historical value of these papyri, become the very people who strive to recover them.

The treatment of Ichneutai by Etman is dominated by his desire to enrich his combination with folk elements, thus he gives singers the role of forming a casual chorus who play folk songs that turn the attendants into a chorus in a particular scene. It is possible however that Etman employs his additional characters to balance the absence of the chorus. As we indicated above, he keeps Grenfell and Hunt as major characters, but adds other characters from contemporary history including the orientalists Nallino and Littmann and Taha Hussein. It is important to note that these additional characters do not actually interact with the characters of Harrison or 


\section{Tragedy and Satyr Play}

Sophocles. They appear only in the first tableau to introduce the central theme which will dominate most of the play. It is worth mentioning that some of these characters correspond to others in Harrison's version; for instance Hussain in defending his proposal to teach the classics in Egyptian universities corresponds to the satyrs' desire to be allowed to use the lyre of Apollo who in Etman's version are represented by the orientalists.

The effect of Sophocles' fragmentary Ichneutai remains dominant in both of the contemporary versions. Each version has its own theme, but if we look closely at these themes we recognize their origin in Sophocles' play. The modern playwright selects subsidiary themes, and then he localizes and develops them, making them central themes in his text to serve his own purposes.

In spite of all the shared characteristics between satyr play and tragedy, these genres were at the same time distinguished from each other, both in antiquity and subsequently. The style, chorus, subject and language patterns are among the main aspects where satyr play is distinguished from tragedy. In addition, the set of values and principles in satyr play is utterly different from the world of tragedy. Several critics today believe that the society in satyr play is a negative image of the Athenian society in the fifth century, specifically of the image of Athenian society presented in tragedy. The result of creating such an uneasy combination is a sort of diversity in literature which reflects the spirit of the fifth century Athens democracy.

\section{Selected bibliography}

Collard, C. and Cropp, M. Eds. (2008). Euripides: Fragments. Cambridge, Mass., Harvard University Press.

Etman, A. (2000). Meiz Albahnasa. Cairo, Almarkaz Alhandsi. Green, R. and E. Handley (1995). Images of the Greek theatre, British Museum.

Frazer, J. G., Ed. (1963). Apollodorus The library. Cambridge, Mass., Harvard University Press. 


\section{Mohammad ALMOHANNA}

Harrison, G. W. M. (2005). Satyr Drama : Tragedy at Play. Swansea, Classical Press of Wales.

Harrison, T. (1991). The Trackers of Oxyrhynchus. London, Faber.

Krumeich, R., et al. (1999). Das Griechische Satyrspiel. Darmstadt, Wissenschaftliche Buchgesellschaft.

Kurtz, D. C., B. A. Sparkes (1982). The Eye of Greece: Studies in the Art of Athens. Cambridge, Cambridge University Press.

Lloyd-Jones, H., Ed. (1996). Sophocles 3: Fragments. . Cambridge, Mass., Harvard University Press.

Rieu, E. V. and . Rieu, D. C. H., (trans.) (2003). Homer: The Iliad. London, Penguin.

Rouse, W. H. D., H. J. Rose and L. R. Lind, Eds. (1940). Nonnos Dionysiaca. Cambridge, Mass., Harvard University Press.

Seaford, R. (1984). Euripides: Cyclops. Oxford, Clarendon.

Sommerstein, A. (2002). Greek Drama and Dramatists. London, Routledge.

Sommerstein, A., Ed. (2008). Aeschylus: Fragments. Cambridge, Mass., Harvard University Press.

Storey, I. and A. Allan (2005). A Guide to Ancient Greek Drama. Oxford, Blackwell.

Sutton, D. f (1974) Father Silenos: Actor or Coryphaeus?. In $C Q$ 24: 1923.

Taplin, O. (1997). The pictorial record. In The_Cambridge Companion to Greek Tragedy. P. E. Easterling (ed.). Cambridge, Cambridge University Press: 69-92.

West, M. L. (1990). Studies in Aeschylus. Stuttgart, Teubner.

\section{Notes}

1 - Allan and Storey (2005) 295.

2 - Sutton (1974) 21 .

3 - Taplin (1997) 73.

4 - Sommerstein (2002) 23-4. 


\section{Tragedy and Satyr Play}

5 - Seaford (1984) 33-9.

${ }^{6}$ - Hom. Il. 6.130-40; Apollod. 3.34; Nonnos Dion 20.226-7, 248-50.

7 - West (1990) 47-48; Sommerstein (2008) 126-127.

8 - Harrison (1991) 55.

9 - Harrison (1990) 61.

10 - The translation of all passages from Etman's play is my own. 